\title{
Endophytic Bacillus cereus Effectively Controls Meloidogyne incognita on Tomato Plants Through Rapid Rhizosphere Occupation and Repellent Action
}

\author{
Hai-Jing Hu, Ya-Li Chen, Yu-Fang Wang, Yun-Yun Tang, Shuang-Lin Chen, and Shu-Zhen Yan, Jiangsu Key Laboratory for Microbes \\ and Functional Genomics, Jiangsu Engineering and Technology Research Center for Industrialization of Microbial Resources, College of Life \\ Sciences, Nanjing Normal University, Nanjing, Jiangsu Province 210023, China
}

\begin{abstract}
Root-knot nematodes (Meloidogyne spp.), which cause severe global agricultural losses, can establish a special niche in the root vascular cylinder of crops, making them difficult to control. Endophytic bacteria have great potential as biocontrol organisms against Meloidogyne incognita. Three endophytic bacteria were isolated from plant tissues and showed high nematicidal activity against $M$. incognita second-stage juveniles (J2) in vitro. The $g y r B$ gene sequence amplification results indicated that the three isolates were Bacillus cereus $\mathrm{BCM} 2, B$. cereus $\mathrm{SZ} 5$, and B. altitudinis CCM7. The isolates colonized tomato roots rapidly and stably during the colonization dynamic experiment. Three pot experiments were designed to determine the potential of three endophytic bacterial isolates on control of rootknot nematodes. The results showed that the preinoculated B. cereus BCM2 experiment significantly reduced gall and egg mass indexes. The inhibition ratio of gall and egg mass was up to 81.2 and $75.6 \%$ on tomato roots and

significantly enhanced shoot length and fresh weight. The other two experiments with inoculated endophytic bacteria and $M$. incognita at the same time or after morbidity had lower inhibition ratios compared with the preinoculated endophytic bacteria experiment. The confocal laser-scanning microscopy method was used to further study the possible mechanism of endophytic bacteria in the biocontrol process. The results showed the localization pattern of the endophytic bacteria B. cereus BCM2-(str')-pBCgfp-1 in tomato root tissues. Root tissue colonized by endophytic bacteria repelled $M$. incognita $\mathrm{J} 2$ infection compared with the untreated control in a repellence experiment. We isolated an endophytic B. cereus strain that stably colonized tomato and controlled $M$. incognita effectively. This strain has potential for plant growth promotion, successful ecological niche occupation, and $M$. incognita $\mathrm{J} 2$ repellent action induction. It plays an important role in endophytic bacteria against root-knot nematodes.
\end{abstract}

Root-knot nematodes (Meloidogyne spp.), which obtain their food exclusively from living cells in roots, are among the most detrimental parasitic nematodes in vegetables and field crops worldwide. Once invading the root, the juveniles migrate intercellularly into the vascular cylinder to establish a permanent feeding site and induce the growth of giant cells that result in the formation of root galls (Gheysen and Fenoll 2002). Root-knot nematodes attack roots and cause severe impairment to plant nutrient and water uptake (Griffiths 1986). The plant-parasitic nematodes caused an estimated \$157 billion losses annually (Abad et al. 2008). Tomato (Lycopersicon esculentum Mill.) is one of the most important vegetable crops in the world. Meloidogyne incognita usually causes severe yield losses of over $30 \%$ in highly susceptible vegetable crops (Sikora and Fernández 2005). Nematodes live in the soil and usually invade underground tissue to established highly specialized feeding structures and occupy the organism permanently, which makes the management and control of nematodes difficult (Radwan et al. 2012).

An endophyte is a kind of organism that colonizes the internal tissue of a plant at some stage during its life cycle without causing plant disease. Both endophytic bacteria and fungi have been shown to be important regulators of plant health (Backman and Sikora 2008), because they share the same niche with nematodes. Currently, there are several potential biocontrol microorganisms with inhibitory activities against nematodes that have been extensively studied. Arthrobotrys oligospora, Paecilomyces lilacinus, Bacillus thuringiensis, and $B$. nematode were systematically investigated in past studies (Niu et al. 2010; Wang et al. 2014; Zhang et al. 2012). Myrothecium verrucaria, Pochonia chlamydosporia, B. firmus, and Pasteuria penetrans have been successfully used to control nematodes in agricultural fields

Corresponding author: S.-Z. Yan; E-mail: yanshuzhen@njnu.edu.cn

*The $\boldsymbol{e}$-Xtra logo stands for "electronic extra" and indicates that three supplementary videos are published online.

Accepted for publication 10 October 2016.

@ 2017 The American Phytopathological Society
(Butt et al. 2001; Kokalis-Burelle 2015; Trudgill et al. 2000; Xiong et al. 2015). Pochonia chlamydosporia is also a commercial biocontrol strain in China and Cuba. B. firmus is the only commercial Bacillus product currently in the market that has been developed in Israel as a biological nematicide agent (Keren-Zur et al. 2000). The evidence described above proves that microorganisms possess a powerful potential for biological control against the root-knot nematode.

Due to their negative impact on the environment and increasing concerns about food safety, many chemical nematicides with high toxicity have been withdrawn or totally forbidden in developed countries (Nico et al. 2004; Schneider et al. 2003). For food safety and human health interests, using biocontrol microorganisms to manage M. incognita is being systematically investigated (Mostafa 2001; Singh et al. 2013). Fast-growing endophytic bacteria are capable of colonizing the internal tissues of plants without causing disease (Ryan et al. 2008; Schulz 2006) and consistently occupying the ecological niche (Hallmann et al. 1997). This fact leads to competition for space and nutrition between endophytes and plant-parasitic nematodes. Complex endophytic bacteria-plant networks and cooccurrence relationships are formed in the root, which gives an advantage to the endophytic bacteria in such competitions with the root-knot nematode (Kerry 2000). Many studies have been conducted on endophytic bacteria for the biological control of plantparasitic nematodes, which were compiled and reported by Sikora et al. (2007). The reports described above suggested that endophytic bacteria can be potential candidates for biocontrol of root-knot nematodes. In the present work, scientists focused on the endophytic bacterial mechanisms of biological control of nematodes, including niche competition, direct toxicity, plant growth promotion, changing exudates, systemic repelling of resistance, and induction (Hashem and Abo-Elyousr 2011; Sikora et al. 2007). Understanding endophytic bacteria interactions with host plants and root-knot nematodes will improve endophyte biocontrol efficiency.

The objective of this study was to screen for an efficient endophytic bacteria strain contributing to reduction of the use of pesticides in the control of root-knot nematodes. We obtained three endophytic bacterial isolates to manage plant-parasitic nematodes on crops. We studied the colonization dynamics of endophytic bacteria BCM2, SZ5, and CCM7 as well as their biocontrol potential 
on $M$. incognita in tomato. To confirm the potential mechanisms in the process of endophytic bacteria biocontrol of root-knot nematodes on tomato, green fluorescent protein (GFP)-tagged B. cereus BCM2 and repellent action experiments were conducted.

\section{Materials and Methods}

Sampling of nematicidal endophytic bacteria and $M$. incognita. Isolate of endophytic bacteria strains. Endophytic bacteria were isolated from the fruit and plant tissues of strawberry, persimmon, chili, and tomato grown in Nanjing, Jiangsu Province, China. Different tissue parts were washed under tap water and surface sterilized by sequential immersion in $70 \%$ (vol/vol) ethanol and $\mathrm{NaClO}(1 \%)$ for 5 min (Suryanarayanan et al. 1998). The explants were washed five times in sterilized water to remove surface sterilization agents. These segments were then incubated on beef extract peptone agar medium ( $3 \mathrm{~g}$ of beef extract, $10 \mathrm{~g}$ of peptone, and $5 \mathrm{~g}$ of $\mathrm{NaCl}$ ) for 1 to 5 days at $28^{\circ} \mathrm{C}$. Single colonies were storage at $-80^{\circ} \mathrm{C}$ in beef extract peptone medium containing $20 \%$ glycerol.

Preparation of second-stage juveniles of $\mathrm{M}$. incognita. Dahong tomato Hezuo903 (L. esculentum Mill.) seed were obtained from the Tomato Institute of Shanghai. Tomato plants were grown under conditions of 28 and $20^{\circ} \mathrm{C}$ (day: $14 \mathrm{~h}$ and night: $10 \mathrm{~h}$, respectively) and $75 \%$ humidity in pots ( $15 \mathrm{~cm}$ in diameter by $14 \mathrm{~cm}$ in height) which contained $1,000 \mathrm{~g}$ of a 1:1 substrate mixture of silica sand and potting soil. M. incognita MIJS3 was provided by Professor Hongmei Li from the Department of Plant Pathology of Nanjing Agriculture University. The $M$. incognita MIJS3 population was maintained on tomato plants. Egg masses were harvested from the root 8 weeks after inoculation. After treatment with $0.5 \% \mathrm{NaClO}$ for 3 min and rinsing with distilled water, the egg masses were put on sieves with $25-\mu \mathrm{m}$ openings suspended over deionized water in plastic bowls, and preparasitic second-stage juveniles (pre-J2) were hatched (Hussey and Barker 1973) The $\mathrm{J} 2$ were then collected using a modified Baerman funnel technique (Gray 1984).

Nematicidal activity of endophytic bacterial isolates in vitro. To determine the nematicidal activity of endophytic bacterial isolates, the purified bacterial strains were cultured in $100 \mathrm{ml}$ of beef extract peptone medium with shaking at $160 \mathrm{rpm}$ and $28^{\circ} \mathrm{C}$ for $60 \mathrm{~h}$. Bacterial culture was centrifuged $(8,000 \mathrm{rpm}, 5 \mathrm{~min})$ and cells were removed from the supernatant with a $0.22-\mu \mathrm{m}$ Millipore filter (Aalten and Gowen 1998). Treatments consisted of (i) medium control and (ii) fermentation liquor of isolates. In total, 100 hatched pre-J2 were added to Eppendorf tube containing $1 \mathrm{ml}$ of medium and isolate supernatant was incubated at $25^{\circ} \mathrm{C}$. Each treatment was replicated 10 times. Mortality rates and different body morphologies of dead nematodes of $\mathrm{J} 2$ were recorded after 6,12 , and $24 \mathrm{~h}$ under a light microscope.

Bacterial identification by sequencing of the $16 \mathrm{~S}$ ribosomal RNA and gyrase B gene. Three strains (BCM2, SZ5, and CCM7) were selected for amplification of the 16S rDNA and gyrase B $(\mathrm{gyrB})$ genes. Genomic DNA was extracted with an Ezup genomic DNA extraction kit from Sangon Biology. 16S ribosomal RNA (rRNA) and $g y r B$ were amplified by PCR with Takara Taq polymerase (Takara Biotechnology). Isolates were first identified by using 16S rRNA gene sequencing. Amplification of the 16S rRNA with the eubacterial universal primers $27 \mathrm{~F}$ and $1492 \mathrm{R}$ was carried out (Lane 1991). The polymerase chain reaction (PCR) was performed by using a 5-min predenaturation at $95^{\circ} \mathrm{C}$; followed by 30 cycles of $94^{\circ} \mathrm{C}$ for $40 \mathrm{~s}, 55^{\circ} \mathrm{C}$ for $40 \mathrm{~s}$, and $72^{\circ} \mathrm{C}$ for $90 \mathrm{~s}$; a final extension step of $10 \mathrm{~min}$ at $72^{\circ} \mathrm{C}$; then, the reaction was held at $4^{\circ} \mathrm{C}$. The $\operatorname{gyr} B$ gene was amplified and sequenced by using the primers UP-f $5^{\prime}$-AGCAGGGTACGGATGTGCGAGC CRTCNACRTCNGCRTCNGCTAT-3' and UP-r 5'-GAAGTCATC ATGACCGTTCTGCAYGCNGGNGGNAARTTYGA-3' (Yamamoto and Harayama 1995) to identify three isolates. The PCR was performed by using a 4-min predenaturation step at $95^{\circ} \mathrm{C}$; followed by 30 cycles of $98^{\circ} \mathrm{C}$ for $10 \mathrm{~s}, 62^{\circ} \mathrm{C}$ for $1 \mathrm{~min}, 72^{\circ} \mathrm{C}$ for $2 \mathrm{~min}$; a final extension $72^{\circ} \mathrm{C}$ for $10 \mathrm{~min}$; and a $4^{\circ} \mathrm{C}$ hold indefinitely. PCR products were purified using the AxyPrep DNA Gel Extraction kit, ligated into the pMD-19T vector, then transformed into Escherichia coli DH5 $\alpha$. Sequencing of the PCR products was conducted by Sangon Biology. The results were queried against the GenBank database with BLAST, and MEGA 5.0 was used to construct a phylogenetic tree.

Colonization dynamic of endophytic bacteria in tomato root. Endophytic bacteria BCM2, SZ5, and CCM7 colonization dynamics were tested by using the spread-plate method. Endophytes were inoculated by root stabbing methods: a 2-cm-wide iron ruler was thrust into the tomato root four to six times before pouring the bacterial suspension into the wound. The population of endophytes in tomato roots were determined at $1,3,5,7,9,11,15,20,25,30,35,40$, 45 , and 50 days postinoculation (dpi). First, the isolates were selected and labeled with the streptomycin sulfate $\left(s t r^{\prime}\right)$ resistance gene (Kumar and Tyagi 1978) so that the isolates were able to grow on plates containing $s t r^{\prime}$ at $300 \mu \mathrm{g} / \mathrm{ml}$. The bacteria cultures were then collected with centrifugation at 8,000 rpm for $5 \mathrm{~min}$. Bacteria cells was diluted with sterile water and the concentrations of BCM2-str', SZ5-str', and CCM7-str' were $2.25 \times 10^{8}, 1.75 \times 10^{8}$, and $1.5 \times$ $10^{8} \mathrm{CFU} / \mathrm{ml}$ and the optical densities at $600 \mathrm{~nm}$ of these suspensions were $0.480,0.441$, and 0.463 , respectively. The suspension $(10 \mathrm{ml})$ was watered onto each 1-month-old tomato plant. Three tomato plants were carefully taken from soil randomly at each dpi, of which $0.2 \mathrm{~g}$ of root was ground after surface disinfection with $70 \%(\mathrm{vol} / \mathrm{vol})$ ethanol and $\mathrm{NaClO}(1 \%)$ for $5 \mathrm{~min}$. The suspension $(200 \mu \mathrm{l})$ was then diluted and spread onto three beef extract peptone agar mediums, each containing $s t r^{\prime}$ at $300 \mu \mathrm{g} / \mathrm{ml}$ to determine the population (CFU per gram of root) of three isolates on tomato roots. Each experiment was carried out twice.

Potential of plant endophytic bacteria to control $M$. incognita and the effect on tomato growth. Three experiments were designed for testing the potential of endophytic bacteria BCM2, SZ5, and CCM7 for biocontrol of the root-knot nematodes and plant growth promotion under greenhouse. Tomato plants (30 days old) obtained from seedling substrates were transplanted into pots, each containing $1,000 \mathrm{~g}$ of soil (as described above). Treatments consisted of (i) $10 \mathrm{ml}$ of sterile water as a control, (ii) $10 \mathrm{ml}$ of Abamectin as a control, (iii) BCM2 suspension, (iv) SZ5 suspension, and (v) CCM7 suspension. The bacterial suspension density was approximately $10^{8} \mathrm{CFU} / \mathrm{ml}$. Each treatment was replicated 10 times. Abamectin (1.8\%) was diluted 3,000-fold with sterile water (Sun et al. 2006). In experiment 1, tomato plants were preinoculated with $10 \mathrm{ml}$ each of the three endophytic bacteria cell suspensions. Two weeks later, for its stable colonization of endophytic bacteria, 1,000 J2 in $2 \mathrm{ml}$ of water were inoculated into 2-cm-deep holes around each tomato stem. A dilution plate counting method was used to calculate the population of endophytes in tomato roots. In experiment 2 , tomato plants were inoculated with $10 \mathrm{ml}$ of endophytic bacterial cell suspensions and $\mathrm{J} 2$ as described above at the same time. In experiment 3, the 1,000 J2 were inoculated for 10 days with gall formed in the plants; then, $10 \mathrm{ml}$ of bacterial suspension was added into holes $2 \mathrm{~cm}$ deep around the stem, following a modified procedure previously reported by Radwan et al. (2012). After 50 dpi of $M$. incognita J2, the number of galls, egg masses per plant, stem height, fresh weight, and dry weight of shoot were determined (Adam et al. 2014). The inhibition ratio (IR) was calculated with the method previously reported (Niu et al. 2012) using the formula IR $=100 \% \times(\mathrm{CN}-\mathrm{TN}) / \mathrm{CN}$, where $\mathrm{CN}$ is the number of galls or egg masses in untreated tomato roots and $\mathrm{TN}$ is the number of galls or egg masses in treated tomato roots.

Colonization pattern of endophytic bacteria on the tomato root. Construction of isolate BCM2 tagged with GFP. To determine the ecological niche and pattern of endophytic bacteria in tomato roots, the B. cereus-BCM2 (str') isolate with the best colonization potential among three isolates in this study was used for GFP tagging. Plasmid $\mathrm{pBC} g f p-1$ was stored in our lab. The competent cells were prepared as previously described (Turgeon et al. 2006). Electroporation of B. cereus BCM2 was carried out as previously described (Cao et al. 2011) with a Bio-Rad Gene Pulser apparatus (Bio-Rad Laboratories) equipped with a Bio-Rad pulse controller. Plasmid $(1 \mu \mathrm{g})$ was added to $100 \mu \mathrm{l}$ of competent cells, and electroporation was carried out in 2-mm electroporation cuvettes (Bio-Rad Laboratories) with the conditions of $2.5 \mathrm{kV}, 200 \Omega$, and $25 \mu \mathrm{F}$. The mixture was incubated 
for $1 \mathrm{~h}$ at $37^{\circ} \mathrm{C}$ and $220 \mathrm{rpm}$; then, the proper amount was plated on Luria-Bertani (LB) agar medium containing kanamycin at $20 \mu \mathrm{g} / \mathrm{ml}$, which was cultured at $37^{\circ} \mathrm{C}$ for $12 \mathrm{~h}$. A single colony was observed under a fluorescence microscope (Imager A1; Zeiss), The growth curve was measured. Colonization amounts in tomato root of BCM2 (str')-pBCgfp-1 were regulated to ensure that the $g f p$-tagged BCM2 produced a sufficiently bright fluorescent signal for singlecell detection without influencing the growth speed and invasion of the isolate.

GFP-tagged B. cereus BCM2 (str') colonization pattern. The colonization patterns of endophytic bacteria on tomato roots were tested with tissue sectioning and detected by confocal laserscanning microscopy (CLSM) observation. The GFP-tagged B. cereus BCM2 (str') was inoculated into tomato plants as described in the previous section. Two weeks later, for its stable colonization, different parts of the tomato roots were monitored by CLSM. The roots taken from soil were washed by tap water, then dipped in $0.05 \% \mathrm{NaClO}$ for $3 \mathrm{~min}$. Different root tissues were detected using a Nikon Ti A1 with 488- and 568-nm band-pass filters to capture the green fluorescence from GFP-tagged BCM2 $\left(s t r^{\prime}\right)$ and the red autofluorescence from the tomato, respectively (Chi et al. 2005).

Repelling effects of endophytic bacteria on $M$. incognita $\mathbf{J} 2$ in vitro. Tomato root fragments $(20 \mathrm{mg}$ ) were placed on a $0.5 \%$ water agar plate to detect the repelling effect of the isolates on J2. Treatments consisted of (i) sterile water and (ii) endophytic bacteria BCM2, SZ5, and CCM7. Each treatment was repeated 10 times. Endophytic bacterial isolates were inoculated on 1-month-old tomato plants (which were grown in sterile soil) and for their stable colonization ( 2 weeks, in this experiment). Tomato plants were harvested, thoroughly washed under tap water, and surface sterilized with $0.05 \% \mathrm{NaClO}$ for $3 \mathrm{~min}$. Roots fragments treated with endophytic bacteria and sterile water were placed on a water agar plate (with $2 \mathrm{~cm}$ distance), and $100 \mathrm{M}$. incognita $\mathrm{J} 2$ in $20 \mu \mathrm{l}$ of sterile water were added in the middle and incubated at $28^{\circ} \mathrm{C}$ in an electroheating standing-temperature cultivator. The movement and infection of $\mathrm{J} 2$ on the water agar plate was observed with an inverted microscope (Olympus IX 71). Fragments of tomato roots were pulverized and the number of $\mathrm{J} 2$ in the roots was recorded after $48 \mathrm{~h}$ under a light microscope (Nikon A1).

Statistical analysis. Data from the experiments were conducted with R software using the "multcomp" R package. Treatments (nematicidal activity in vitro, colonization dynamics, and biocontrol of $M$. incognita) were compared by one-way analysis of variance $(P \leq 0.05)$, When a significant $F$ value was determined, means were separated by Tukey's multiple comparison test. For compare the repelling effects of three isolates, the $P$ value was adjusted by
Dunnett's test. Data from colonization numbers were transformed to $\log x$ for analysis (Poonguzhali et al. 2008).

\section{Results}

Screening endophytic isolates with nematicidal activity. Twelve endophytic bacteria strains were isolated from the plant tissues. Based on the nematicidal activity $(P \leq 0.05)$ and different appearances of dead nematodes in vitro after 6,12 , and $24 \mathrm{~h}$ of treatment with the isolate's suspension, the mortality rate of the 12 isolates was above $90 \%$, Three endophytic bacterial isolates (BCM2, SZ5, and CCM7) were used for further experiments (Table 1).

Identification of three isolates by sequencing of $16 \mathrm{~S}$ rRNA and gyrB genes. The 16S rRNA gene was amplified and sequenced for species identification. Sequences of the $16 \mathrm{~S}$ rRNA gene were comparatively analyzed by using the BLAST algorithm in the GenBank nucleotide sequence database. However, the alignment was not specific enough for identification. Therefore, we did more identifications by combinations of $g y r B$ gene sequencing and biochemical experiments (data not shown). The results indicated that the isolates BCM2 and SZ5 fit to B. cereus and CCM7 fit to B. altitudinis. A phylogenetic neighbor-joining tree was constructed to determine the taxonomic relationships of the three isolates (Fig. 1). The GenBank accession numbers of BCM2, SZ5, and CCM7 were KT923659, KT923660, and KT923661, respectively.

Colonization dynamics of endophytic bacterial isolates in the tomato root. Three isolates rapidly proliferated in large quantities within $7 \mathrm{dpi}$ on the tomato root. The population of endophytic bacteria in the roots was stable, with $\geq 10^{3} \mathrm{CFU} / \mathrm{g}$ fresh weight until $50 \mathrm{dpi}$ (Fig. 2). Differences between the three isolates in tomato roots after inoculation were recorded. BCM2 was found to have the strongest colonization ability, and the maximum density of cells was $3.53 \times$ $10^{6} \mathrm{CFU} / \mathrm{g}$ fresh weight at $9 \mathrm{dpi}$ on the tomato root; overall colonization was significantly higher than for SZ5 and CCM7 $(P \leq 0.05)$.

Potential of endophytic bacteria in biocontrol of $M$. incognita and plant growth promotion effect in tomato. Pot experiment results indicated that inoculation of B. cereus BCM2, B. cereus SZ5, and $B$. altitudinis $\mathrm{CCM} 7$ in tomato roots in different experiments reduced the number of galls and egg masses compared with sterile water at 50 dpi (Table 2). BCM2 was shown to have the highest IR with respect to galls and egg masses on tomato roots by up to 81.2 and $75.6 \%$, higher than the positive control abamectin at 73.8 and $60 \%$ $(P \leq 0.05)$. Where endophytic bacteria and $M$. incognita were inoculated at the same time, the bacteria also had reduced numbers of galls and egg masses; however, the effect on the IR of galls and egg masses was lower compared with the preinoculation of endophytic bacteria $(P \leq 0.05)$. Preinoculation with $M$. incognita before bacteria inoculation did not show a solid effect of the three bacterial

Table 1. Endophytic bacterial isolates screened in this experiment and nematicidal activity of Meloidogyne incognita in vitro ${ }^{\mathrm{x}}$

\begin{tabular}{|c|c|c|c|c|c|c|}
\hline \multirow[b]{2}{*}{ Ser. ${ }^{\mathbf{y}}$} & \multicolumn{3}{|c|}{ Mortality rate } & \multirow[b]{2}{*}{ Source } & \multirow[b]{2}{*}{ Tissue } & \multirow[b]{2}{*}{ Symptom $^{z}$} \\
\hline & $6 \mathrm{~h}$ & $12 \mathrm{~h}$ & $24 \mathrm{~h}$ & & & \\
\hline $\mathrm{BCM} 2$ & $87.0 \pm 5.4 \mathrm{a}$ & $91.3 \pm 5.2 \mathrm{a}$ & $100 \pm 0.0 \mathrm{a}$ & Fragaria ananassa & Fruit & Seepage \\
\hline CCM3 & $21.2 \pm 9.1 \mathrm{~cd}$ & $86.9 \pm 3.0 \mathrm{ab}$ & $99.2 \pm 0.8 \mathrm{ab}$ & F. ananassa & Fruit & Seepage \\
\hline CCM7 & $78.9 \pm 1.8 \mathrm{ab}$ & $90.2 \pm 1.2 \mathrm{a}$ & $100 \pm 0.0 \mathrm{a}$ & F. ananassa & Fruit & Degradation \\
\hline CCM9 & $71.8 \pm 4.6 \mathrm{~b}$ & $86.9 \pm 2.4 \mathrm{ab}$ & $100 \pm 0.0 \mathrm{a}$ & F. ananassa & Fruit & Degradation \\
\hline DP1 & $72.2 \pm 4.4 \mathrm{~b}$ & $85.9 \pm 2.6 \mathrm{ab}$ & $97.4 \pm 1.8 \mathrm{ab}$ & Lycopersicon esculentum & Fruit & Rigidity \\
\hline DP8 & $9.6 \pm 2.5 \mathrm{de}$ & $31.6 \pm 7.4 \mathrm{~d}$ & $98.2 \pm 1.7 \mathrm{ab}$ & L. esculentum & Fruit & Rigidity \\
\hline DP10 & $11.3 \pm 1.9 \mathrm{de}$ & $71.4 \pm 2.4 \mathrm{~b}$ & $100 \pm 0.0 \mathrm{a}$ & L. esculentum & Fruit & Seepage \\
\hline DP12 & $7.7 \pm 3.1 \mathrm{de}$ & $43.9 \pm 4.4 \mathrm{~cd}$ & $90.9 \pm 4.5 \mathrm{~b}$ & L. esculentum & Fruit & Rigidity \\
\hline DP24 & $7.4 \pm 7.4 \mathrm{de}$ & $52.4 \pm 5.9 \mathrm{c}$ & $99.4 \pm 0.6 \mathrm{ab}$ & L. esculentum & Fruit & Rigidity \\
\hline SZ5 & $71.5 \pm 5.1 \mathrm{~b}$ & $94.1 \pm 6.2 \mathrm{a}$ & $100 \pm 0.0 \mathrm{a}$ & Diospyros kaki L.f & Fruit & Rigidity \\
\hline XG32 & $19.2 \pm 6.7 \mathrm{~cd}$ & $46.9 \pm 8.4 \mathrm{c}$ & $98.4 \pm 1.1 \mathrm{ab}$ & Capsicum aпnиum Linn. & Root & Rigidity \\
\hline YC1 & $28.4 \pm 2.2 \mathrm{c}$ & $41.8 \pm 7.3 \mathrm{~cd}$ & $92.1 \pm 2.6 \mathrm{~b}$ & C. апnиuт Linn. & Root & Rigidity \\
\hline $\mathrm{CK}$ & $0 \pm 0 \mathrm{e}$ & $0.9 \pm 0.4 \mathrm{e}$ & $1.6 \pm 1.1 \mathrm{c}$ & $\ldots$ & $\ldots$ & $\ldots$ \\
\hline
\end{tabular}

${ }^{\mathrm{x}}$ Data are represented as the mean \pm standard deviation $(n=10)$. Within each column, values followed by different letters are significantly different $(P \leq 0.05)$ according to one-way analysis of variance and Tukey's multiple comparison test.

y Serial number.

${ }^{\mathrm{z}}$ Symptom of death. 
isolates on the reduction of the galls and egg masses compared with other treatments mentioned before $(P \leq 0.05)$, and the level was only half that of the abamectin control (Table 2). The results above indicate that precolonization of endophytic bacteria appeared to be able to reduce the number of galls and egg masses in the tomato, and the IR of the endophytic bacteria to the galls and egg masses was almost the same as with the chemical nematicide. Moreover, there is a close correlation between the biological control effect and the colonization of the bacteria population in the roots.

The growth parameters presented in Table 2 revealed that the three endophytic bacterial isolates have different effects on plant growth. All of them increased shoot length of tomato but, among the three isolates tested, only the preinoculated treatment with B. cereus BCM2 enhanced shoot length and fresh weight significantly $(P \leq 0.05)$ (Table 2$)$.

Construction of GFP-tagged strain BCM2. The strong fluorescence signal of GFP-tagged B. cereus BCM2 was detected under a fluorescence microscope (Fig. 3A), and the plasmid was stable for 6 months. The growth curve of B. cereus BCM2-str'-gfp was the same as wild-type $B$. cereus BCM 2 cultured in $100 \mathrm{ml}$ of LB within $108 \mathrm{~h}$ (Fig. 3B). B. cereus BCM2-str'-gfp reached $3.95 \times 10^{5} \mathrm{CFU} / \mathrm{g}$ at $7 \mathrm{dpi}$, indicating that carriage of the GFP gene did not change the colonization ability of $B$. cereus BCM2.

Colonization pattern of GFP-tagged endophytic bacteria BCM2. The GFP-tagged B. cereus BCM2 was tested for endophytic bacterial colonization patterns in tomato roots. Roots were examined by monitoring the green fluorescent cells of GFP-tagged colonizers around the tissue of tomato roots containing the epidermis, cortex, and vascular cylinder (Fig. 4). The fluorescent bacteria preferentially colonized around the lysed plant cells and root hair in the root epidermis (Fig. $4 \mathrm{~B}$ and E). Laser three-dimensional scanning technology was applied to examine the strong fluorescent signal of younger root interiors (Fig. 4A). The GFP-tagged B. cereus BCM2 gathered in large numbers in lateral roots and junctions (Fig. 4B and C). They developed either as single cells or small clusters within intercellular spaces from cortex to vascular cylinder (Fig. 4C to E). More GFP-tagged cell clusters were detected between the giant cells caused by $M$. incognita in the roots of diseased tomato plants (Fig. 4F) as compared with the pattern in nematode-free tomato roots (Fig. 4G).

Repellent action of endophytic bacteria colonized in the tomato root during $\boldsymbol{M}$. incognita invasion. Most $\mathrm{J} 2$ migrated to roots containing no endophytic bacteria at the same distance as in treated roots (inoculated with the endophytic bacteria). At $24 \mathrm{~h}$ after placement of $\mathrm{J} 2$ on the plate, under a light microscope, we detected that $\mathrm{J} 2$ were attacking the roots not inoculated with endophytic bacteria (Fig. 5B). A low number of $\mathrm{J} 2$ was recovered from roots which were inoculated with three endophytic bacterial isolates $48 \mathrm{~h}$ after $M$. incognita $\mathrm{J} 2$ were placed on the water agar plate compared with the sterile water control (Fig. 5C). The attraction assay revealed that most
$\mathrm{J} 2$ preferred the untreated plant roots. The results indicate that $M$. incognita $\mathrm{J} 2$ appeared to respond to repelling action on the roots treated with endophytic bacteria (Fig. 5).

\section{Discussion}

Antagonistic bacteria are often considered to be effective microorganisms for the biocontrol of root-knot nematodes (Adam et al. 2014; Hashem and Abo-Elyousr 2011; Xiong et al. 2015), as well as plant growth-promoting bacteria (Munif et al. 2000; Sturz and Kimpinski 2004; Vetrivelkalai et al. 2010). Nevertheless, few studies were performed on the possibility that $B$. cereus and B. altitudinis as endophytic bacteria could provide biocontrol of $M$. incognita. Root colonization of endophytic bacteria is a prerequisite for a successful biocontrol agent to be able to establish efficient protection (de Weert and Bloemberg 2006; Weng et al. 2013). In this work, we reported three endophytic bacteria which possess strong nematicidal activity against $M$. incognita based on successful colonization.

As previously reported, biocontrol efficiency was closely related to the colonization density and degree to which niche competition was the main mode for endophytes within the root system (Sikora et al. 2007). However, low levels of G12 colonization in potato and Arabidopsis roots were related to a high level of biocontrol effectiveness in their experiment (Hallmann et al. 2001; Hasky-Günther et al. 1998). In our experiment, endophytic Bacillus spp. which occupied the ecology niche rapidly increased in population up to $3.53 \times$ $10^{6} \mathrm{CFU} / \mathrm{g}$ of root $9 \mathrm{dpi}$. Two weeks later, the population of endophytic bacterial colonization stabilized in tomato roots and was maintained at $10^{3} \mathrm{CFU} / \mathrm{g}$ of root for 50 days. The bacterial endophytes in our experiment demonstrated a large ability to establish and persist

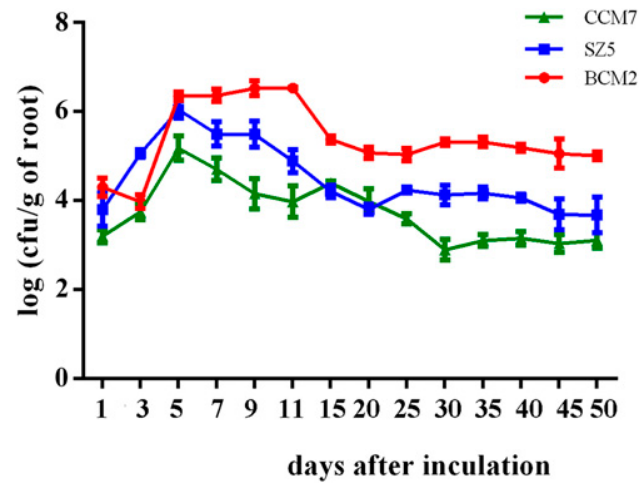

Fig. 2. Population of Bacillus cereus BCM2 (str'), B. cereus SZ5 (str'), and B. altitudinis CCM7 (str') on tomato roots. Population is expressed in log $x(\mathrm{CFU} / \mathrm{g})$ of roots ( $y$ axis) and days ( $x$ axis).

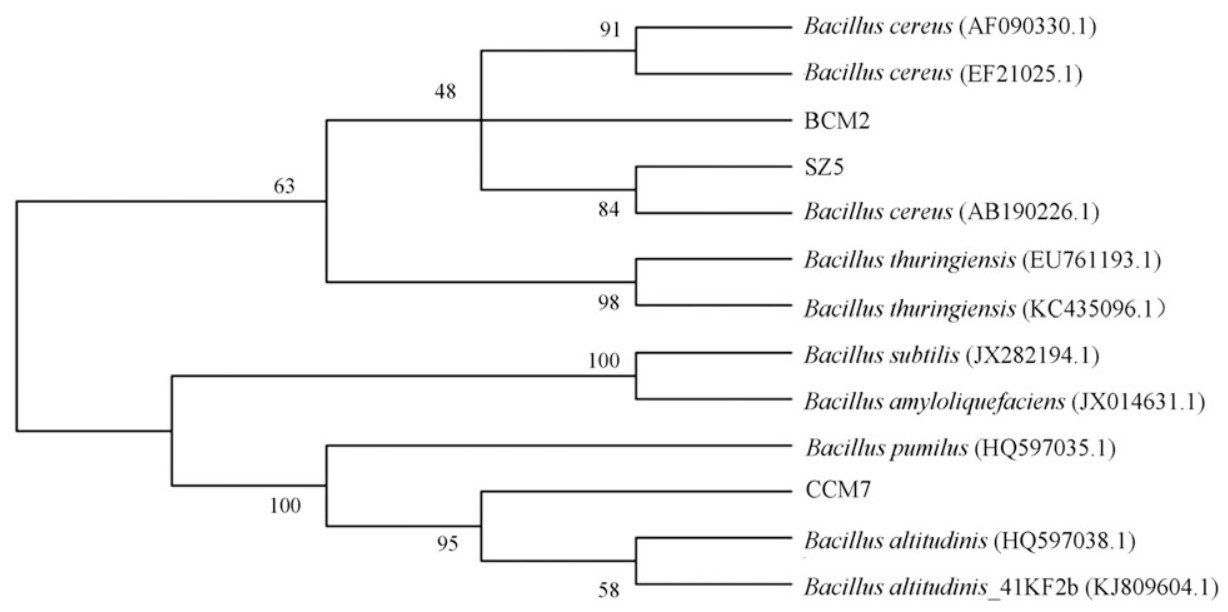

Fig. 1. Neighbor-joining phylogeny depicting phylogenetic relationships of Bacillus cereus, B. altitudinis, and other allied genera based on combined analysis of gyrB gene sequences. Bootstrap values above $50 \%$ are given above branches. 
either on the surface (data not shown) or in the root, and the amount of colonization was higher than previous observations of endophytic bacterial population in roots of $10^{3}$ to $10^{5}$ cells/g fresh weight (Hallmann et al. 1997; Vetrivelkalai et al. 2010). In our opinion, in order to efficiently protect the root system against the attack of phytopathogenic microorganisms, a biocontrol strain has to establish itself in the rhizosphere. It has also been considered that effective root colonization is a crucial step for subsequent biocontrol (de Weert and

Table 2. Endophytic bacteria Bacillus cereus BCM2 and SZ5 and B. altitudinis CCM7 in biological control potential of Meloidogyne incognita and effect on the growth parameters of tomato plants infected with $M$. incognita in three treatments of pot experiment ${ }^{\mathrm{x}}$

\begin{tabular}{|c|c|c|c|c|c|}
\hline \multirow[b]{2}{*}{ Treatment } & \multicolumn{2}{|c|}{$\begin{array}{l}\text { Inhibition } \\
\text { rate }(\%) \text { of }\end{array}$} & \multicolumn{3}{|c|}{ Stem $^{z}$} \\
\hline & Gall & $\begin{array}{l}\text { Egg } \\
\text { mass }\end{array}$ & Length & $\begin{array}{l}\text { Fresh } \\
\text { weight }\end{array}$ & $\begin{array}{c}\text { Dry } \\
\text { weight }\end{array}$ \\
\hline \multicolumn{6}{|l|}{ Experiment 1} \\
\hline Sterile water & $\ldots$ & $\ldots$ & $30.3 \pm 4.6$ & $6.6 \pm 1.3$ & $0.7 \pm 0.1$ \\
\hline Abamectin & $73.8 \mathrm{~b}$ & $60.0 \mathrm{ab}$ & $32.1 \pm 5.1$ & $6.7 \pm 2.5$ & $0.7 \pm 0.3$ \\
\hline BCM2 & $81.2 \mathrm{a}$ & $75.6 \mathrm{a}$ & $35.2 \pm 3.0^{*}$ & $9.3 \pm 2.1^{*}$ & $0.9 \pm 0.3$ \\
\hline SZ5 & $72.6 \mathrm{~b}$ & $43.5 \mathrm{ab}$ & $31.0 \pm 4.8$ & $6.5 \pm 1.8$ & $0.8 \pm 0.2$ \\
\hline CCM7 & $70.1 \mathrm{~b}$ & $53.0 \mathrm{ab}$ & $34.1 \pm 3.3$ & $8.3 \pm 3.1$ & $0.7 \pm 0.3$ \\
\hline \multicolumn{6}{|l|}{ Experiment 2} \\
\hline Sterile water & $\ldots$ & $\ldots$ & $30.7 \pm 5.2$ & $6.3 \pm 1.6$ & $0.6 \pm 0.2$ \\
\hline Abamectin & $78.8 \mathrm{~b}$ & $66.8 \mathrm{ab}$ & $31.0 \pm 2.3$ & $6.6 \pm 1.2$ & $0.7 \pm 0.2$ \\
\hline BCM2 & $77.8 \mathrm{~b}$ & $66.8 \mathrm{ab}$ & $32.0 \pm 4.7$ & $7.3 \pm 2.0$ & $0.7 \pm 0.2$ \\
\hline SZ5 & $68.0 \mathrm{ab}$ & $62.6 \mathrm{ab}$ & $33.3 \pm 4.3$ & $7.3 \pm 2.4$ & $0.7 \pm 0.2$ \\
\hline CCM7 & $56.6 \mathrm{ac}$ & $40.4 a b$ & $32.6 \pm 4.3$ & $6.9 \pm 1.5$ & $0.6 \pm 0.2$ \\
\hline \multicolumn{6}{|l|}{ Experiment 3} \\
\hline Sterile water & $\ldots$ & $\ldots$ & $31.6 \pm 2.6$ & $6.7 \pm 2.3$ & $0.7 \pm 0.3$ \\
\hline Abamectin & $61.9 \mathrm{bc}$ & $63.2 \mathrm{ab}$ & $32.1 \pm 5.5$ & $7.0 \pm 2.9$ & $0.8 \pm 0.4$ \\
\hline BCM2 & $32.0 \mathrm{c}$ & $38.1 \mathrm{ab}$ & $33.8 \pm 2.6$ & $7.5 \pm 1.6$ & $0.7 \pm 0.2$ \\
\hline SZ5 & $42.7 \mathrm{bcd}$ & $38.3 \mathrm{ab}$ & $32.1 \pm 5.5$ & $7.3 \pm 3.6$ & $0.8 \pm 0.5$ \\
\hline CCM7 & $35.0 \mathrm{~cd}$ & $29.5 \mathrm{~b}$ & $30.9 \pm 4.1$ & $6.8 \pm 2.3$ & $0.7 \pm 0.2$ \\
\hline
\end{tabular}

${ }^{\mathrm{x}}$ Data are represented as the mean \pm standard deviation $(n=10)$.

y Values followed by different letters are significantly different $(P \leq 0.05)$ according to one-way analysis of variance and Tukey's multiple comparison test.

${ }^{\mathrm{z}}$ Values followed by an asterisk (*) are significantly different in random design tests at $P \leq 0.05$ under Tukey's multiple comparison test; values followed by nothing indicate that the result was not significantly different $(P \leq 0.05)$.
Bloemberg 2006; Weng et al. 2013). This finding is supported by our results that $B$. cereus BCM2 established in tomato root rapidly, with a strong potential to reduce root galling and egg mass production by $M$. incognita under greenhouse conditions. There is a corresponding low biological control effect with low numbers of SZ5 and CCM7 cells in roots. This indicates that an increase in competitive colonization ability could result in improved biocontrol ability (Barahona et al. 2011). There is a close relationship between the biological control effect and colonization population of endophytic $B$. cereus.

The results from the pot experiments testing $B$. cereus $\mathrm{BCM} 2$ and SZ5 and B. altitudinis CCM7 provided evidence of biocontrol of $M$. incognita, as well as of plant growth promotion. Many bacterial endophytes have been reported to promote growth and health and inhibit nematode pests of crop plants (Chi et al. 2005; Munif et al. 2000; Sikora et al. 2007; Sturz et al. 2000; Vetrivelkalai et al. 2010). However, B. cereus and B. altitudinis endophytes have been poorly studied as biocontrol agents. Comparing the efficiency of bacterial endophyte biocontrol of $M$. incognita in three experiments, infection by the root-knot nematode $M$. incognita was significantly reduced by endophyte precolonization. In this work, preisolations were able not only to biocontrol $M$. incognita in tomato but also to promote plant growth. According to the report of Vos et al. (2013), bacterial endophytes triggered plants to develop a defense response after colonization, which activated the tomato roots more efficient or rapid defense mechanisms when they were subsequently attacked by root-knot nematodes. This provided an explanation of root-knot nematode management by endophyte bacteria.

Beneficial bacteria could induce systemic resistance against $M$. incognita in tomato plants (Adam et al. 2014). The bacterial induction of systemic resistance (ISR) of the host plant has been discovered and researched (Backman and Sikora 2008). Previous research used the split-root design of tomato roots to detect induced resistance (Mwangi 2002; Racke and Sikora 1992). ISR might explain how endophytic bacteria biologically control the plant-parasitic nematode (Sikora et al. 2007). In recent works, researchers proposed that endophytes might enhance the activity of defense-related biomolecules and enzymes against $M$. incognita (Singh et al. 2013; Vos et al. 2013). There is still no final conclusion about the details of biocontrol mechanisms of endophytic bacteria modifying root exudates and ISR, which should be further studied.

Endophytic bacteria Bacillus spp. often colonize the primary root surface, which is the zone of differentiation, elongation, and lateral root junctions (Cao et al. 2011). Around lateral root junctions, Sinorhizobium meliloti 1021 gathered through entry into the root interior
A

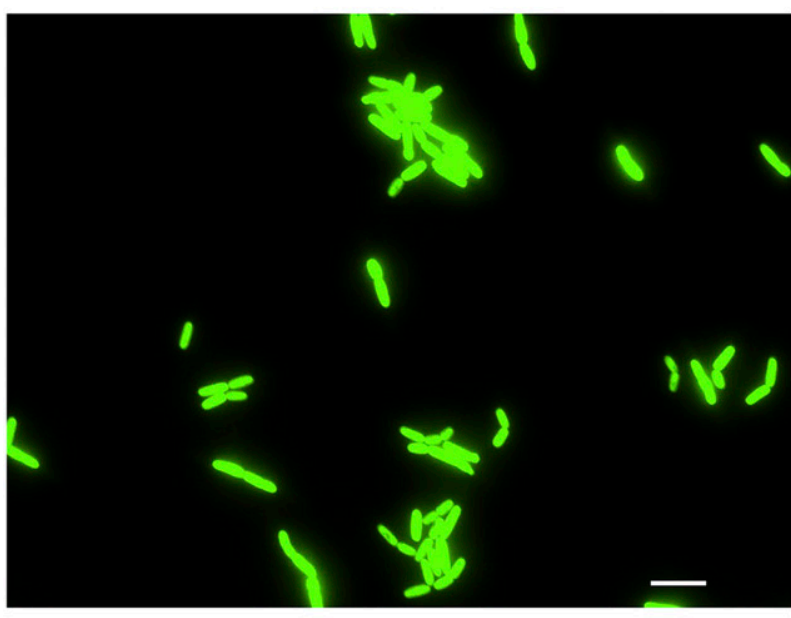

B

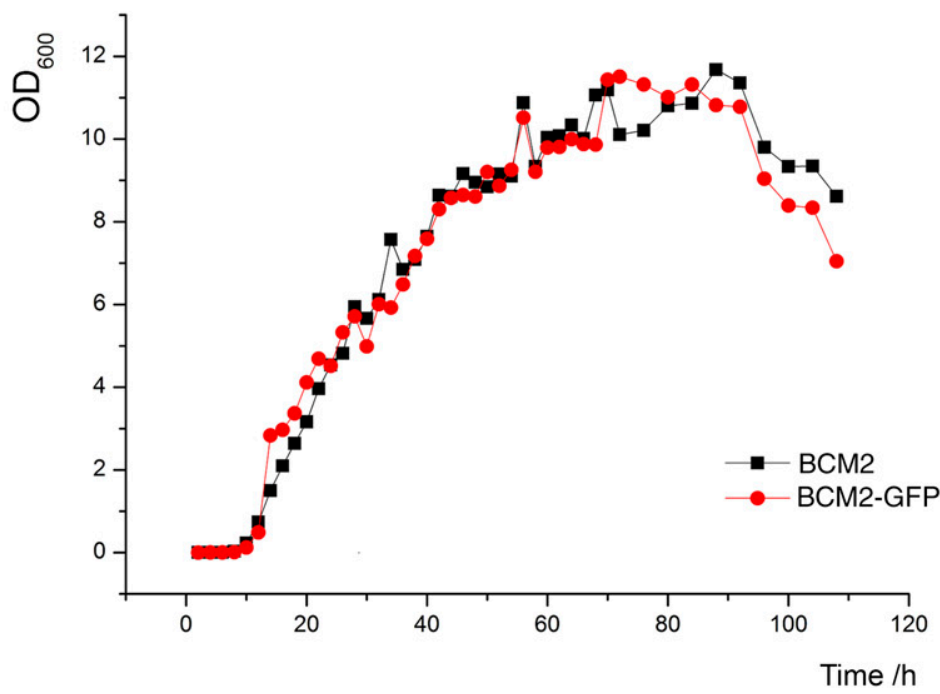

Fig. 3. A, Fluorescence micrograph (Zeiss A1) observe of green fluorescent protein (GFP)-tagged Bacillus cereus BCM2. B. cereus BCM2-str'-gfp after incubation in Luria-Bertani medium (LB) for $12 \mathrm{~h}$. The bar represents $10 \mu \mathrm{m}$. B, Population of B. cereus BCM2-str' and B. cereus BCM2 (str')-pBCgfp-1 represented by optical density at $600 \mathrm{~nm}$ observed during 1 to $108 \mathrm{~h}$ after incubation in LB. 


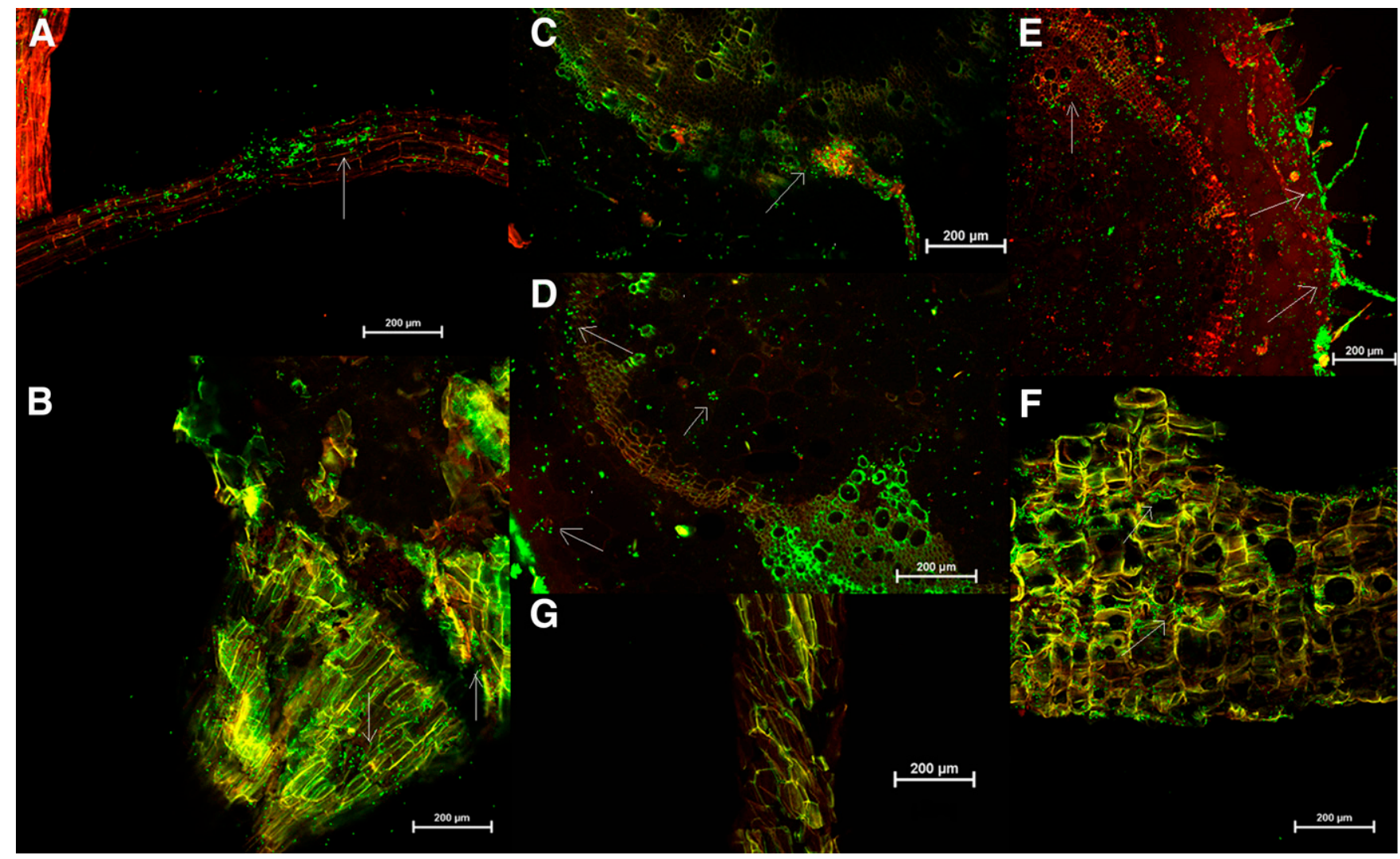

Fig. 4. Confocal laser-scanning microscopy analysis of endophytic bacteria Bacillus cereus BCM2 (str')-pBCgfp-1 in tomato root tissue after inoculated for 7 days. The bar indicates $200 \mu \mathrm{m}$. A, Distribution of green fluorescent protein (GFP)-tagged BCM2 in new root; B, distribution of GFP-tagged BCM2 in lateral root; C, GFP signal was gathered in lateral root junctions; D, GFP-tagged BCM2 gathered small clusters to intercellular spaces from cortex to vascular cylinder; $\mathbf{E}$, endophytic bacteria occupied the space of root hair and epidermal cells in tomato roots; F, more clusters were detected in giant cells in the root of disease tomato caused by Meloidogyne incognita; and $\mathbf{G}$, tomato root uninoculated.

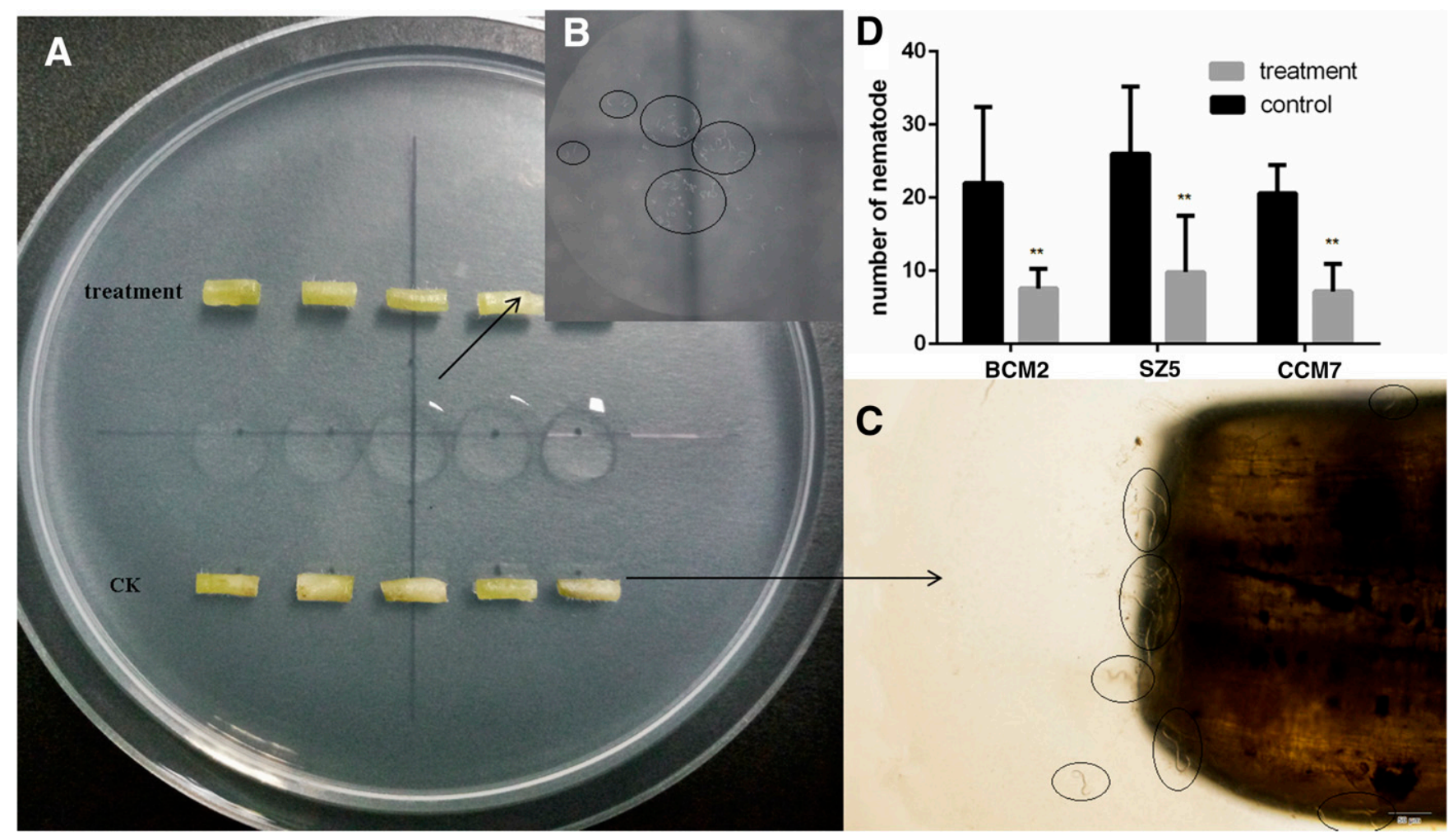

Fig. 5. Meloidogyne incognita second-stage juvenile (J2) repelling action when tomato roots were treated with three endophytic bacteria. A, Endophytic bacteria-treated and sterile water-treated tomato roots on water agar plate; B, $100 \mathrm{M}$. incognita $\mathrm{J} 2$ in $20 \mu \mathrm{l}$ of water; C, more $\mathrm{M}$. incognita $\mathrm{J} 2$ invaded tomato roots not inoculated with endophytic bacteria; and D, the number of $M$. incognita J2 in different tomato roots; asterisks $\left.{ }^{* *}\right)$ indicate significantly different $(P \leq 0.001$, Dunnett test, $n=10)$ from control (no endophytic bacteria). 
between displaced epidermal cells (Chi et al. 2005), which was also detected in this work. As previously reported (Prieto et al. 2011), root hairs also play a key role in endophytic bacterial colonization of their host. It has been reported that GFP-tagged bacteria occupied intercellular spaces of epidermal cells in the roots of tomato (Poonguzhali et al. 2008). In this work, GFP-tagged B. cereus BCM2 gathered in large numbers at the lateral root and junctions, and also developed as either single cells or small clusters in intercellular spaces from cortex to vascular cylinder. As previously reported, root-knot nematodes invading the plant added a competition site of endophytic bacterial colonization (Hallmann et al. 1998). We observed this phenomenon by GFP-tagged B. cereus BCM 2 on CLSM for the first time; between the cells of hyperplasia and abnormal tissues, more clusters of endophyte cells were detected.

Endophytic B. cereus colonized the root surface or in intercellular space. The most direct effect was related to the production of metabolites and modulation of root secretion (Singh et al. 2013) to change nematode infection. It has been remarked that bacteria are promising biocontrol agents because of the direct effects on metabolites to induce mortality in $\mathrm{J} 2$ or enhance host defense mechanisms in roots (Hashem and Abo-Elyousr 2011). As previously reported, B. megaterium caused repellence of $M$. graminicola in rice roots (Padgham and Sikora 2007). Our results were also consistent with reports (Dababat 2007; Dababat and Sikora 2007) which demonstrated that M. incognita mostly chose the control plants lacking treatment with Fusarium oxysporum. Olfactory chemotaxis toward food-associated odors is among the most common behaviors of nematodes (Niu et al. 2010). From our in vitro experiment results, roots which have been colonized by endophytic bacteria had a lower probability of invasion by $M$. incognita $\mathrm{J} 2$. It is hypothesized that the reduction of the invasion index might be attributed to endophytic bacterial colonization, which changes the metabolites of host plant roots. It has been recognized that endophytes alter root exudate patterns and most likely influence the egg hatching, recognition, and attraction behavior of rootknot nematodes (Sikora et al. 2007), suggested as an explanation of repellent action in our experiment. Functional genomics could uncover the reason for systemic changes in roots after treatment with endophytic bacteria that led to their reduced attractiveness to nematodes (Backman and Sikora 2008). It has also been reported that endophytes have the potential to modulate the metabolism of host plants and, accordingly, the nutrient values of different lettuce varieties (Cardinale et al. 2015).

This study explored the potential of endophytic bacteria isolated from plants to biocontrol $M$. incognita in tomato plants under greenhouse conditions. Three potential isolates (B. cereus BCM2 and SZ5 and B. altitudinis CCM7) were applied to study the colonization dynamics in tomato roots. Our results showed that endophytic bacteria colonized roots in large numbers, and stability in tomato plants was a precondition of biocontrol of $M$. incognita under greenhouse conditions. It was also noted that endophytic bacteria precolonized tomato roots with more biological control potential of $M$. incognita in the pot experiment. The GFP-tagged strains and CLSM were introduced to detect the ecological niche of endophytic bacteria after invading the plants. We obtained direct evidence of the endophytic Bacillus sp. pattern in tomato roots. Endophytic bacteria colonized in tomato roots repelled $M$. incognita $\mathrm{J} 2$ on water agar plates. This indirect evidence suggests that endophytic bacteria modify the root exudates of plants.

\section{Acknowledgments}

We thank H. Li at the Department of Plant Pathology in Nanjing Agriculture University for kindly providing the egg masses of $M$. incognita. This work was supported by Project BK2012848 of the National Sanitation Foundation of Jiangsu Province of China.

\section{Literature Cited}

Aalten, P., and Gowen, S. 1998. Entomopathogenic nematodes and fluorescent Pseudomonas rhizosphere bacteria inhibiting Radopholus simlis invasion in banana roots. Brighton Crop Prot. Conf. Pests Dis. 2:675-680.

Abad, P., Gouzy, J., Aury, J. M., Castagnone-Sereno, P., Danchin, E. G., Deleury, E., and Caillaud, M. C. 2008. Genome sequence of the metazoan plant-parasitic nematode Meloidogyne incognita. Nat. Biotechnol. 26:909-915.
Adam, M., Heuer, H., and Hallmann, J. 2014. Bacterial antagonists of funga pathogens also control root-knot nematodes by induced systemic resistance of tomato plants. PLoS One 9:e90402.

Backman, P. A., and Sikora, R. A. 2008. Endophytes: An emerging tool for biological control. Biol. Control 46:1-3.

Barahona, E., Navazo, A., Martínez-Granero, F., Zea-Bonilla, T., PérezJiménez, R. M., Martín, M., and Rivilla, R. 2011. Pseudomonas fluorescens F113 mutant with enhanced competitive colonization ability and improved biocontrol activity against fungal root pathogens. Appl. Environ. Microbiol. 77:5412-5419.

Butt, T. M., Jackson, C., and Magan, N., eds. 2001. Fungi as Biocontrol Agents: Progress Problems and Potential. CAB International, Wallingford, UK.

Cao, Y., Zhang, Z., Ling, N., Yuan, Y., Zheng, X., Shen, B., and Shen, Q. 2011. Bacillus subtilis SQR 9 can control Fusarium wilt in cucumber by colonizing plant roots. Biol. Fertil. Soils 47:495-506.

Cardinale, M., Grube, M., Erlacher, A., Quehenberger, J., and Berg, G. 2015. Bacterial networks and co-occurrence relationships in the lettuce root microbiota. Environ. Microbiol. 17:239-252.

Chi, F., Shen, S.-H., Cheng, H.-P., Jing, Y.-X., Yanni, Y. G., and Dazzo, F. B 2005. Ascending migration of endophytic rhizobia, from roots to leaves, inside rice plants and assessment of benefits to rice growth physiology. Appl Environ. Microbiol. 71:7271-7278.

Dababat, A. E.-F. 2007. Importance of the mutualistic endophyte Fusarium oxysporum 162 for enhancement of tomato transplants and the biological control of the root-knot nematode Meloidogyne incognita, with particular reference to mode-of-action. Dissertation. Cuvillier Verlag, University of Bonn, Germany.

Dababat, A. E.-F. A., and Sikora, R. A. 2007. Influence of the mutualistic endophyte Fusarium oxysporum 162 on Meloidogyne incognita attraction and invasion. Nematology 9:771-776

de Weert, S., and Bloemberg, G. V. 2006. Rhizosphere competence and the role of root colonization in biocontrol. Pages 317-333 in: Plant-Associated Bacteria. S. S. Gnanamanickam, ed. Springer, Berlin.

Gheysen, G., and Fenoll, C. 2002. Gene expression in nematode feeding sites Annu. Rev. Phytopathol. 40:191-219.

Gray, N. 1984. Ecology of nematophagous fungi: Comparison of the soil sprinkling method with the Baermann funnel technique in the isolation of endoparasites. Soil Biol. Biochem. 16:81-83.

Griffiths, B. 1986. Mineralization of nitrogen and phosphorus by mixed cultures of the ciliate protozoan Colpoda steinii, the nematode Rhabditis sp. and the bacterium Pseudomonas fluorescens. Soil Biol. Biochem. 18 637-641.

Hallmann, J., Quadt-Hallmann, A., Mahaffee, W., and Kloepper, J. 1997. Bacteria endophytes in agricultural crops. Can. J. Microbiol. 43:895-914.

Hallmann, J., Quadt-Hallmann, A., Miller, W., Sikora, R., and Lindow, S. 2001 Endophytic colonization of plants by the biocontrol agent Rhizobium etl G12 in relation to Meloidogyne incognita infection. Phytopathology 91: 415-422.

Hallmann, J., Quadt-Hallmann, A., Rodríguez-Kábana, R., and Kloepper, J. 1998. Interactions between Meloidogyne incognita and endophytic bacteria in cotton and cucumber. Soil Biol. Biochem. 30:925-937.

Hashem, M., and Abo-Elyousr, K. A. 2011. Management of the root-knot nematode Meloidogyne incognita on tomato with combinations of different biocontrol organisms. Crop Prot. 30:285-292.

Hasky-Günther, K., Hoffmann-Hergarten, S., and Sikora, R. A. 1998. Resistance against the potato cyst nematode Globodera pallida systemically induced by the rhizobacteria Agrobacterium radiobacter (G12) and Bacillus sphaericus (B43). Fundam. Appl. Nematol. 21:511-517.

Hussey, R., and Barker, K. 1973. Comparison of methods of collecting inocula of Meloidogyne spp., including a new technique. Plant Dis. Rep. 57:1025-1028.

Keren-Zur, M., Antonov, J., Bercovitz, A., Feldman, K., Husid, A., Kenan, G., Marcov, N., and Rebhun, M. 2000. Bacillus firmus formulations for the safe control of root-knot nematodes. Pages 47-52 in: Proc. Brighton Crop Prot. Conf. Pests Dis. Vol. 1, Brighton, UK

Kerry, B. R. 2000. Rhizosphere interactions and the exploitation of microbial agents for the biological control of plant-parasitic nematodes. Annu. Rev. Phytopathol. 38:423-441

Kokalis-Burelle, N. 2015. Pasteuria penetrans for control of Meloidogyne incognita on tomato and cucumber, and $M$. arenaria on snapdragon. J. Nematol. 47:207-213.

Kumar, H., and Tyagi, M. 1978. Intergeneric transfer of streptomycin-resistance marker between two blue-green algae. In: Proc. Indian Acad. Sci. Sect. B. Springer, India. 225-230.

Lane, D. J. 1991. 16S/23S rRNA sequencing. Pages 115-175 in: Nucleic Acid Techniques in Bacterial Systematics. E. Stackebrandt and M. Goodfellow, eds. John Wiley and Sons, New York.

Mostafa, F. A. M. 2001. Integrated control of root-knot nematodes, Meloidogyne spp. infecting sunflower and tomato. Pak. J. Biol. Sci. 4:44-46.

Munif, A., Hallmann, J., Sikora, R. 2000. Evaluation of the biocontrol activity of endophytic bacteria from tomato against Meloidogyne incognita. Meded. Fac. Landbouwkd. Toegepaste Biol. Wet. (Univ. Gent). 65:471-480.

Mwangi, M. 2002. Mechanisms of action in biological control of Fusarium oxysporum f. sp. lycopersici in tomato using rhizobacteria. Reinische FriedrichWilhelms-Universität, Institut für Pflanzenkrankheiten. University of Bonn, Germany. 
Nico, A. I., Jimenez-Diaz, R. M., and Castillo, P. 2004. Control of root-knot nematodes by composted agro-industrial wastes in potting mixtures. Crop Prot. 23:581-587.

Niu, H., Zhao, L., Lu, M., Zhang, S., and Sun, J. 2012. The ratio and concentration of two monoterpenes mediate fecundity of the pinewood nematode and growth of its associated fungi. PLoS One 7:e31716.

Niu, Q. H., Huang, X. W., Zhang, L., Xu, J. P., Yang, D. M., Wei, K. B., Niu, X. M., An, Z. Q., Bennett, J. W., Zou, C. G., Yang, J. K., and Zhang, K. Q. 2010. A Trojan horse mechanism of bacterial pathogenesis against nematodes. Proc. Natl. Acad. Sci. USA 107:16631-16636.

Padgham, J., and Sikora, R. 2007. Biological control potential and modes of action of Bacillus megaterium against Meloidogyne graminicola on rice. Crop Prot. 26:971-977.

Poonguzhali, S., Madhaiyan, M., Yim, W. J., Kim, K. A., and Sa, T. M. 2008. Colonization pattern of plant root and leaf surfaces visualized by use of green-fluorescent-marked strain of Methylobacterium suomiense and its persistence in rhizosphere. Appl. Microbiol. Biotechnol. 78:1033-1043.

Prieto, P., Schilirò, E., Maldonado-González, M. M., Valderrama, R., BarrosoAlbarracín, J. B., and Mercado-Blanco, J. 2011. Root hairs play a key role in the endophytic colonization of olive roots by Pseudomonas spp. with biocontrol activity. Microb. Ecol. 62:435-445.

Racke, J., and Sikora, R. 1992. Influence of the plant health-promoting rhizobacteria Agrobacterium radiobacter and Bacillus sphaericus on Globodera pallida root infection of potato and subsequent plant growth. J. Phytopathol. 134:198-208.

Radwan, M. A., Farrag, S. A. A., Abu-Elamayem, M. M., and Ahmed, N. S. 2012. Biological control of the root-knot nematode, Meloidogyne incognita on tomato using bioproducts of microbial origin. Appl. Soil Ecol. 56:58-62.

Ryan, R. P., Germaine, K., Franks, A., Ryan, D. J., and Dowling, D. N. 2008. Bacterial endophytes: Recent developments and applications. FEMS Microbiol. Lett. 278:1-9.

Schneider, S. M., Rosskopf, E. N., Leesch, J. G., Chellemi, D. O., Bull, C. T., and Mazzola, M. 2003. United States Department of Agriculture-Agricultural Research Service research on alternatives to methyl bromide: Pre-plant and post-harvest. Pest Manage. Sci. 59:814-826.

Schulz, B. 2006. Pages 261-279 in: Mutualistic Interactions with Fungal Root Endophytes. Springer, Berlin, Heidelberg, Germany.

Sikora, R. A., and Fernández, E. 2005. Nematode parasites of vegetables. Pages 319-392 in: Plant Parasitic Nematodes in Subtropical and Tropical Agriculture. M. Luc, R. A. Sikora, and J. Bridge, eds. CABI.

Sikora, R. A., Schafer, K., and Dababat, A. A. 2007. Modes of action associated with microbially induced in planta suppression of plant-parasitic nematodes. Australas. Plant Pathol. 36:124-134.

Singh, U. B., Sahu, A., Sahu, N., Singh, B. P., Singh, R. K., Renu, Singh, D. P., Jaiswal, R. K., Sarma, B. K., Singh, H. B., Manna, M. C., Rao, A. S., and Prasad, S. R. 2013. Can endophytic Arthrobotrys oligospora modulate accumulation of defence related biomolecules and induced systemic resistance in tomato (Lycopersicon esculentum Mill.) against root knot disease caused by Meloidogyne incognita. Appl. Soil Ecol. 63:45-56.
Sturz, A., Christie, B., and Nowak, J. 2000. Bacterial endophytes: Potential role in developing sustainable systems of crop production. Crit. Rev. Plant Sci. 19:1-30.

Sturz, A., and Kimpinski, J. 2004. Endoroot bacteria derived from marigolds (Tagetes spp.) can decrease soil population densities of root-lesion nematodes in the potato root zone. Plant Soil 262:241-249.

Sun, M. H., Gao, L., Shi, Y. X., Li, B. J., and Liu, X. Z. 2006. Fungi and actinomycetes associated with Meloidogyne spp. eggs and females in China and their biocontrol potential. J. Invertebr. Pathol. 93:22-28.

Suryanarayanan, T., Kumaresan, V., and Johnson, J. 1998. Foliar fungal endophytes from two species of the mangrove Rhizophora. Can. J. Microbiol. 44: 1003-1006.

R Development Core Team. 2008. R: A Language and Environment for Statistical Computing. R Foundation for Statistical Computing, Vienna.

Trudgill, D. L., Blok, V. C., Bala, G., Daudi, A., Davies, K. G., Gowen, S. R., Fargette, M., Madulu, J. D., Mateille, T., Mwageni, W., Netscher, C. Phillips, M. S., Sawadogo, A., Grivino, C. G., and Voyoukallou, E. 2000. The importance of tropical root-knot nematodes (Meloidogyne spp.) and factors affecting the utility of Pasteuria penetrans as a biocontrol agent. Nematology 2:823-845.

Turgeon, N., Laflamme, C., Ho, J., and Duchaine, C. 2006. Elaboration of an electroporation protocol for Bacillus cereus ATCC 14579. J. Microbiol. Methods 67:543-548.

Vetrivelkalai, P., Sivakumar, M., and Jonathan, E. 2010. Biocontrol potential of endophytic bacteria on Meloidogyne incognita and its effect on plant growth in bhendi. J. Biopest. 3:452-457.

Vos, C., Schouteden, N., van Tuinen, D., Chatagnier, O., Elsen, A., De Waele, D., Panis, B., and Gianinazzi-Pearson, V. 2013. Mycorrhiza-induced resistance against the root-knot nematode Meloidogyne incognita involves priming of defense gene responses in tomato. Soil Biol. Biochem. 60:45-54.

Wang, X., Li, G. H., Zou, C. G., Ji, X. L., Liu, T., Zhao, P. J., Liang, L. M., Xu, J. P., An, Z. Q., Zheng, X., Qin, Y. K., Tian, M. Q., Xu, Y. Y., Ma, Y. C., Yu, Z. F., Huang, X. W., Liu, S. Q., Niu, X. M., Yang, J. K., Huang, Y., and Zhang, K. Q. 2014. Bacteria can mobilize nematode-trapping fungi to kill nematodes. Nat. Commun. 5: Article number 5776. doi:10.1038/ncomms6776

Weng, J., Wang, Y., Li, J., Shen, Q., and Zhang, R. 2013. Enhanced root colonization and biocontrol activity of Bacillus amyloliquefaciens SQR9 by $a b r B$ gene disruption. Appl. Microbiol. Biotechnol. 97:8823-8830.

Xiong, J., Zhou, Q., Luo, H., Xia, L., Li, L., Sun, M., and Yu, Z. 2015. Systemic nematicidal activity and biocontrol efficacy of Bacillus firmus against the rootknot nematode Meloidogyne incognita. World J. Microbiol. Biotechnol. 31: 661-667.

Yamamoto, S., and Harayama, S. 1995. PCR amplification and direct sequencing of $g y r B$ genes with universal primers and their application to the detection and taxonomic analysis of Pseudomonas putida strains. Appl. Environ. Microbiol. 61:1104-1109.

Zhang, F., Peng, D., Ye, X., Yu, Z., Hu, Z., Ruan, L., and Sun, M. 2012. In vitro uptake of $140 \mathrm{kDa}$ Bacillus thuringiensis nematicidal crystal proteins by the second stage juvenile of Meloidogyne hapla. PLoS One 7:e38534. 